\title{
Salivary parameters and oral health status amongst adolescents in Mexico
}

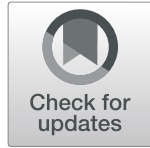

\author{
A. E. González-Aragón Pineda', A. García Pérez ${ }^{1 *}$ (D) and F. García-Godoy²
}

\begin{abstract}
Background: In the last years an increased interest in the use of salivary parameters in connection with caries experience and caries prediction has been shown. In schoolchildren investigations are known, where the relationship between caries prevalence and salivary parameters has been assessed, but in the adolescent population studies are scarce. The aim of the study was evaluate of the association among salivary parameters, oral health status and caries experience in adolescents in Mexico.

Methods: A cross-sectional study was conducted on 256 (DMFT $\geq 5$ ) and 165 (DMFT< 5) 12-to- 14-year-old adolescents. From all the adolescents, unstimulated mid-morning saliva samples were collected, after which the salivary flow rate was calculated, and the salivary $\mathrm{pH}$ and buffer capacity was measured. The caries was evaluated via the application of the DMFT score. Clinical variables such as oral hygiene and dental calculus were examined in the adolescent's oral cavity. The adolescents provided data on their personal characteristics by completing a questionnaire, while socioeconomic data were collected from their parents. Descriptive, bivariate and logistic regression model analyses were performed.
\end{abstract}

Results: The prevalence of caries was $61.1 \%$ (DMFT $\geq 5$ ) in permanent dentition, with $72.7 \%$ of subjects presenting poor oral hygiene. The mean levels of salivary flow rate, $\mathrm{pH}$, and buffer capacity was significantly lower $(p<0.05)$ in adolescents with caries score of DMFT $\geq 5$ than in those with caries score of DMFT $<5$. Salivary flow and buffer capacity were higher in boys than in girls. The logistic regression model applied showed that adolescents with a salivary flow rate $<1 \mathrm{ml}$ per min were more likely to present caries [OR $=1.58(\mathrm{Cl} 195 \% 1.04-2.40) ; p=0.033$ ] than adolescents with a flow rate $\geq 1 \mathrm{ml}$ per-min, and that, for each unit of increased $\mathrm{pH}$, the probability of presenting caries reduced by $76 \%$ [OR $=0.24$ (C195\% 0.10-0.55); $p=0.001]$.

Conclusion: Significant association was found in salivary flow rate, $\mathrm{pH}$ and buffer capacity in adolescents with caries (DMFT $\geq 5$ ). In addition to differences of these parameters by sex, the results suggest saliva parameters may act as indicators of caries in adolescents.

Keywords: Dental caries, Saliva analysis, Adolescents, Oral health

\footnotetext{
*Correspondence: alvaro.garcia@unam.mx

${ }^{1}$ Faculty of Higher Studies (FES), Iztacala, National Autonomous University of Mexico (UNAM), Avenida de los Barrios Número 1, Colonia Los Reyes Ixtacala, C.P. 54090 Tlalnepantla, Estado de México, Mexico

Full list of author information is available at the end of the article
}

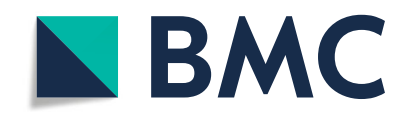

(c) The Author(s). 2020 Open Access This article is licensed under a Creative Commons Attribution 4.0 International License, which permits use, sharing, adaptation, distribution and reproduction in any medium or format, as long as you give appropriate credit to the original author(s) and the source, provide a link to the Creative Commons licence, and indicate if changes were made. The images or other third party material in this article are included in the article's Creative Commons licence, unless indicated otherwise in a credit line to the material. If material is not included in the article's Creative Commons licence and your intended use is not permitted by statutory regulation or exceeds the permitted use, you will need to obtain permission directly from the copyright holder. To view a copy of this licence, visit http://creativecommons.org/licenses/by/4.0/. The Creative Commons Public Domain Dedication waiver (http://creativecommons.org/publicdomain/zero/1.0/) applies to the data made available in this article, unless otherwise stated in a credit line to the data. 


\section{Background}

Dental caries is the commonest disease worldwide affecting a large proportion of the population round the globe [1]. The dental tissues demineralization is due to the acidic byproducts resulting from the bacterial fermentation of sugar [2]. Some of these organic acidic bacterial products are the acetic, lactic and propionic acids, which have the ability to dissolve hydroxyapatite [3]. The most relevant acidproducing bacterial species are: Streptococcus mutans, Streptococcus Sobrinus, Bifidobacterium dentium, Bifidobacterium spp, Scardovia wiggsiae, and lactobacilli [4]. A complex mixture of fluids produced by various salivary glands and crevicular fluid [5], saliva promotes the natural beneficial relationship between the resident and host oral microbiota, affecting local $\mathrm{pH}$ via its damping properties and thus, contributing to the establishment of stable and diverse microbial communities [6, 7]. Saliva also plays an important role in remineralization, providing calcium, phosphate, and fluoride to dental tissue $[8,9]$.

Salivary flow is an important factor since it favors the cleaning of bacterial substrates, protects the oral surfaces and helping to control the development of caries. A reduced salivary flow is able of producing a cascade of events where the biofilm accumulates and matures, resulting in the acidification of the microenvironment and the selection of acidogenic bacteria [6,7]. Perhaps the best clinical indicator of saliva's protective properties would be salivary flow rate, as other salivary parameters ( $\mathrm{pH}$ and buffer capacity) depend on it [8].

Factors such as age, sex, and inadequate oral hygiene are elements that change the oral environment [10], with the mechanical control of biofilm via proper toothbrushing twice a day considered to help maintain healthy gums, in addition to preventing the development of mature bacterial communities and increasing the probability that the microbiota remains acidogenic-bacteria free [11]. On the other hand, it has been observed that as age increases, the greater the caries experience in permanent dentition due to various risk factors, data on caries experience in adolescents in Mexico have reported prevalence of $80.0 \%$ with a DMFT mean of 4.05 ( \pm 3.47$)$ [12], likewise, a longitudinal study of adolescents in Sweden found an increase in the DMFT mean of $4.5( \pm 6.1)$ after 5 years [13].

Although published studies have found an association between the presence of caries and poor salivary parameters (reduced salivary flow rate, and low $\mathrm{pH}$ and/or buffer capacity) [14, 15], other studies have found this association to be inconsistent [16]. While its influence is recognized, more evidence of this association is required, thus motivating the objective of this cross-sectional study, which is to evaluate the association among salivary parameters as salivary flow rate, $\mathrm{pH}$, buffer capacity, oral health status and dental caries experience in adolescents in Mexico. The hypothesis proposed in the present study is that the mean levels of salivary flow rate, $\mathrm{pH}$, and buffer capacity will be lower in adolescents with caries scores of DMFT $\geq 5$ than in those with caries scores of DMFT < 5. Moreover, salivary parameters such as salivary flow and buffer capacity will be higher in boys compared to girls.

\section{Methods}

\section{Ethical approval}

This cross-sectional study's research protocol was reviewed and approved by the Ethics Committee of the Faculty of Higher Studies Iztacala at the National Autonomous University of Mexico (CE/FESI/102017/1209). Before any measurements were taken, written informed consent was obtained from the parents/guardians of all participating subjects.

\section{Characteristics of the study location}

This study adhered to a cross-sectional design. Mexico City is made up of 16 territorial demarcations and the chosen demarcation was Gustavo A. Madero, located to the north of the city and was chosen due to the socioeconomic level of the population. The area selected had a population of $1,185,772$ inhabitants $(13.2 \%$ of the total population of Mexico City), of whom, 41.4\% over 15 years of age have been educated up to elementary level and $79.2 \%$ have access to health services. The Consejo Nacional de Población (CONAPO or National Population Council) indicates a medium level of socioeconomic activity in the study area [17]. For convenience, two schools located in the north of Mexico City were selected. The sample size for the present study was set based on the prevalence of caries in this age cohort, as revealed by previous studies [18]. With a power of 0.80 , an alpha of 0.05 , and an odds ratio equal to 1.80 , the required sample size was 415 , with 457 participants invited to participate, assuming a $10 \%$ non-response rate. A final sample size of 421 subjects, of the 457 invited to participate, was obtained, with 36 subjects excluded. The inclusion criteria were adolescents aged between 12 and 14 years old; of either gender; with written authorization to participate in the study. The exclusion criteria: physically and medically compromised subjects; subjects who were taking medication; and, subjects who did not attend the saliva sampling.

\section{Variables and data collection}

The variables included in the study were as follows: sex (girls/boys); age (in years); toothbrushing frequency (number of times a day) dichotomized into $<2$ times a day and $\geq 2$ times a day; use of fluoride toothpaste (yes/ no); the Simplified Oral Hygiene Index (OHI-S) dichotomized into poor (OHI-S $\geq 2$ score), dental calculus (yes/ 
no), and good hygiene (OHI-S $<2$ score); flow rate (milliliters per minute) dichotomized into $(<1 \mathrm{ml} / \mathrm{min})$ and ( $\geq 1 \mathrm{ml} / \mathrm{min}$ ); $\mathrm{pH}$ of stimulated saliva; buffer capacity (high, medium, and low); stimulated salivary flow, obtained in adherence with standard procedures [19]; and, the subject's mother's level of education (Primary or less, secondary, Technical or University).

Dental caries was evaluated in permanent dentition using the World Health Organization (WHO) criteria based on the decayed (D), missing (M), and filled $(\mathrm{F})$ teeth (DMFT) score and grouped into two categories $(\mathrm{DMFT}<5$ or DMFT $\geq 5)$ [20]. Adolescents having at least five decayed tooth requiring restoration were taken as caries active subjects according to the WHO criteria.

The clinical oral evaluations were conducted by one dentist using dental mirrors (\# 5), WHO dental probes, and artificial light, with the subject's teeth brushed prior to the evaluation. One examiner participated in a prestudy calibration exercise (theoretical training) with the DMFT score. The measurements to be used by the dentist conducting the oral examination had already been standardized with those of a gold standard evaluator (an expert dentist), obtaining Cohen's kappa coefficients for intra-rater reliability of 0.84 and 0.89 for dental caries and oral hygiene, respectively.

Information on toothbrushing frequency, use of fluoride toothpaste, and the subject's mother's level of education were gathered through a standardized self-reported questionnaire.

\section{Measurement of saliva properties}

All the saliva measurements were made and analyzed in the schools, immediately after taking them. Samples were not stored. Subjects were instructed to neither consume food or drinks nor brush their teeth and/or wash their mouth an hour before the measurements were taken, which took place between 8:00 and 10:00 am to reduce the influence of circadian variations on salivary flow mean. The $\mathrm{pH}$ of saliva at rest was determined through a strip because it was measured at the beginning, using a small amount of saliva. On the other hand, the stimulated $\mathrm{pH}$ was determined through a potentiometer because this was done in the saliva collected period for $5 \mathrm{~min}$. The flow rate and buffer capacity were also measured in stimulated saliva. The process comprised the following steps [19]:

1. $\mathrm{pH}$ of saliva at rest: The student was asked to deposit a drop of unstimulated saliva into a collection vessel, with a pH test strip (Saliva-Check Buffer kit GC America Inc., USA) then placed in contact with the saliva, at rest, for $10 \mathrm{~s}$ and then cross-referenced with the manufacturer's standard.
The salivary $\mathrm{pH}$ was directly estimated using a $\mathrm{pH}$ test strip.

2. Stimulated saliva flow rate: Each student was given a piece of flavorless chewing gum and asked to stimulate the production of saliva for $30 \mathrm{~s}$ and then swallow the saliva, which was collected every minute for $5 \mathrm{~min}$. A YS series electronic scale (Ohaus Corporation, Mexico City, Mexico) was used, considering the equivalence of $1 \mathrm{mg}=1 \mathrm{ml}$, to weigh the saliva collected, with the weight then divided by the number of minutes of collection ( $\mathrm{ml} /$ min).

3. The $\mathrm{pH}$ of the stimulated saliva: A potentiometer with a specialized electrode (Starter ST2100; Ohaus Corporation) was used to measure the $\mathrm{pH}$ of the stimulated saliva.

4. Buffer capacity: A drop of saliva was applied over the three fields of a buffer test strip (Saliva-Check Buffer kit, GC America Inc., USA) for an expected 2 min reaction, from which the buffer capacity was determined using the reference values provided by the manufacturer (high, medium or low).

\section{Statistical analysis}

First, a descriptive analysis of the population was performed using measures of central tendency and dispersion for the quantitative variables, and frequency and percentage values for the qualitative variables. Bivariate analysis was then performed to establish the relationship between the independent variables in the adolescent subjects with DMFT $\geq 5$ and DMFT $<5$, using the Pearson Chi-squared test for categorical variables and the Wilcoxon rank-sum test and Kruskal-Wallis test for numerical variables. The association between salivary parameters (salivary flow, $\mathrm{pH}$, and buffer capacity) and dental caries (DMFT $\geq 5$ ) was evaluated by means of multiple logistic regression models adjusted for confounders (oral hygiene, toothbrushing frequency and mother's level of education), with the Odds Ratio (OR) calculated to a 95\% Confidence Interval (95\% CI). Model diagnostic tests were conducted using the HosmerLemeshow goodness of fit test and the statistical analysis of extreme values, while, finally, possible interactions were analyzed, with values of $p \leq 0.05$ considered statistically significant, using the Stata 15 program (Stata Corp, College Station, TX, USA).

\section{Results}

Of the 421 participants in the present study, the mean age was $12.3( \pm 0.46)$ years, while the percentage of girls and boys examined was 53.0 and $47.0 \%$, respectively. No significant difference was found for mean age by sex $(p=0.055)$. Our findings revealed that $33.7 \%$ of the students brushed their teeth twice or more times per day 
and $66.3 \%$ once per day or less and $95.8 \%$ using toothpaste, while, according to the OHI-S evaluation, $72.7 \%$ of subjects had poor oral hygiene.

The prevalence of caries $(\mathrm{DMFT} \geq 5)$ in permanent dentition was $61.1 \%$, while the mean DMFT score was 5.96 ( \pm 3.98$)$, with statistically significant differences observed based on gender (boys $5.1 \pm 3.6$, and girls $6.6 \pm$ $4.1, p<0.05)$, the largest component of the DMFT score was decayed teeth with $76.6 \%$, followed by filled teeth with $23.4 \%$. No permanent tooth was recorded as lost. The prevalence of caries was higher in adolescents with poor oral hygiene than adolescents with good oral hygiene $(68.0 \%$ vs $32.0 \%, p=0.007)$. The values for sex, age, toothbrushing frequency, oral hygiene, dental calculus, and the subject's mother's level of education are summarized in Table 1.

Table 2 shows the data for salivary parameters associated with DMFT score. The mean for the salivary $\mathrm{pH}$ stimulated was lower in the DMFT $\geq 5$ group than in the DMFT $<5$ group (7.2 vs. $7.4 ; p=0.001$, respectively). The prevalence of caries $(\mathrm{DMFT} \geq 5)$ was higher in the decreased salivary flow group $(<1 \mathrm{ml}$ per-min) than in the normal salivary flow group $(59.8 \%$ vs. $40.2 \%$, respectively; $p=0.004)$. Regarding the buffer capacity, the prevalence of caries (DMFT $\geq 5$ ) was higher in the low buffer capacity group than in the high buffer capacity group $(29.3 \%$ vs. $9.0 \%$, respectively; $p=0.020)$. Salivary $\mathrm{pH}(r=-0.247, p=0.001)$ and buffer capacity $(r=-$ $0.152 ; p=0.001)$ findings both showed a significant negative correlation with the DMFT score.
Table 2 Distribution of salivary parameters in adolescents from 12 to 14 years with DMFT $\geq 5$ vs DMFT $<5$ from Mexico

\begin{tabular}{llll}
\hline & $\begin{array}{l}\text { DMFT }<\mathbf{5} \boldsymbol{n}=\mathbf{1 6 5} \\
\text { Mean }\left(\mathbf{S D}^{\mathbf{a}}\right)\end{array}$ & $\begin{array}{l}\text { DMFT } \geq \mathbf{5} \boldsymbol{n}=\mathbf{2 5 6} \\
\text { Mean }\left(\mathbf{S D}^{\mathbf{a}}\right)\end{array}$ & $\mathbf{p}$ \\
\hline Resting pH & $7.1( \pm 0.49)$ & $6.9( \pm 0.54)$ & $0.001^{\mathrm{b}}$ \\
Salivary pH stimulated & $7.4( \pm 0.25)$ & $7.2( \pm 0.28)$ & $0.001^{\mathrm{b}}$ \\
$\begin{array}{l}\text { Flow rate } \\
\geq 1 \mathrm{ml} \text { per-min }\end{array}$ & $90(54.6)$ & $103(40.2)$ & \\
$\quad<1 \mathrm{ml}$ per-min & $75(45.4)$ & $153(59.8)$ & \\
Buffer capacity & & & \\
$\quad$ High & $28(17.0)$ & $23(9.0)$ & $0.04^{\mathrm{c}}$ \\
Medium & $102(61.8)$ & $158(61.7)$ & \\
Low & $35(21.2)$ & $75(29.3)$ & \\
\hline
\end{tabular}

${ }^{a} S D$ Standard Deviation ${ }^{b}$ Wilcoxon rank-sum (Mann-Whitney) test ${ }^{c}$ Chi-squared test

Table 3 shows that salivary flow and buffer capacity were higher in boys than in girls. Table 4 shows the data related to the multivariate logistic regression analysis conducted for caries (DMFT $\geq 5)$. Subjects with a toothbrushing frequency $<2$ times a day were more likely to present caries $[\mathrm{OR}=1.68(\mathrm{CI} 95 \% 1.07-2.63) ; p=0.023$ ] than those with a toothbrushing frequency $\geq 2$ times a day, while subjects with a salivary flow rate $<1 \mathrm{ml}$ permin were found to be more likely to have caries than those with a salivary flow rate $\geq 1 \mathrm{ml}$ per-min $[\mathrm{OR}=1.58$ (CI95\% 1.04-2.40); $p=0.033$ ]. Additionally, the variables of sex, oral hygiene, and the subject's mother's

Table 1 Characteristic oral health in adolescents from 12 to 14 years from Mexico

\begin{tabular}{|c|c|c|c|}
\hline & DMFT $<5 n=165$ & $\mathrm{DMFT} \geq 5 n=256$ & Value $p$ \\
\hline Age & $12.3( \pm 0.53)$ & $12.4( \pm 0.55)$ & $0.055^{\mathrm{a}}$ \\
\hline \multicolumn{4}{|l|}{ Sex } \\
\hline Boys & $90(54.6)$ & $108(42.2)$ & \multirow[t]{2}{*}{$0.013^{b}$} \\
\hline Girls & $75(45.4)$ & $148(57.8)$ & \\
\hline \multicolumn{4}{|l|}{ Toothbrushing frequency } \\
\hline$<2$ times a day & $119(72.1)$ & $160(62.5)$ & \multirow[t]{2}{*}{$0.042^{b}$} \\
\hline$\geq 2$ times a day & $46(27.9)$ & $96(37.5)$ & \\
\hline \multicolumn{4}{|l|}{ Oral hygiene (OHI-S) } \\
\hline Good hygiene & $33(20.0)$ & $82(32.0)$ & \multirow[t]{2}{*}{$0.007^{b}$} \\
\hline Poor hygiene & $132(80.0)$ & $174(68.0)$ & \\
\hline \multicolumn{4}{|l|}{ Dental Calculus } \\
\hline No & $111(67.3)$ & $186(72.7)$ & \multirow[t]{2}{*}{$0.237^{b}$} \\
\hline Yes & $54(32.7)$ & $70(27.3)$ & \\
\hline \multicolumn{4}{|l|}{ Mother's level of education } \\
\hline Primary or less & $35(21.2)$ & $60(23.4)$ & \multirow[t]{3}{*}{$0.027^{b}$} \\
\hline Secondary & $53(32.1)$ & $109(42.6)$ & \\
\hline Technical or University & $77(46.7)$ & $87(34.0)$ & \\
\hline
\end{tabular}

${ }^{a}$ Wilcoxon rank-sum (Mann-Whitney) test ${ }^{\mathrm{b}}$ Chi-squared test 
Table 3 Distribution of salivary parameters in adolescents from 12 to 14 years from Mexico by sex

\begin{tabular}{llll}
\hline & $\begin{array}{l}\text { Boys } \boldsymbol{n}=\mathbf{1 9 8} \\
\text { Mean }\left(\mathbf{S D}^{\mathbf{a}}\right)\end{array}$ & $\begin{array}{l}\text { Girls } \boldsymbol{n}=\mathbf{2 2 3} \\
\text { Mean }\left(\mathbf{S D}^{\mathbf{a}}\right)\end{array}$ & $\mathbf{p}$ \\
\hline Resting pH & $6.91( \pm 0.55)$ & $6.99( \pm 0.50)$ & $0.038^{\mathrm{b}}$ \\
Salivary pH stimulated & $7.29( \pm 0.28)$ & $7.24( \pm 0.27)$ & $0.048^{\mathrm{b}}$ \\
$\begin{array}{l}\text { Flow rate } \\
\geq 1 \mathrm{ml} \text { per-min }\end{array}$ & $101(51.0)$ & $92(41.3)$ & $0.045^{\mathrm{c}}$ \\
$\quad<1 \mathrm{ml}$ per-min & $97(49.0)$ & $131(58.7)$ & \\
$\begin{array}{l}\text { Buffer capacity } \\
\text { High }\end{array}$ & $35(17.8)$ & $16(7.1)$ & $<0.001^{\mathrm{c}}$ \\
$\quad$ Medium & $128(65.0)$ & $134(59.8)$ & \\
Low & $34(17.2)$ & $74(33.1)$ & \\
\hline
\end{tabular}

${ }^{\mathrm{a} S D}$ Standard Deviation ${ }^{\mathrm{b}}$ Wilcoxon rank-sum (Mann-Whitney) test ${ }^{c}$ Chi-squared test

educational level were positively associated with the presence of caries (DMFT $\geq 5$ ).

\section{Discussion}

The present study found an association between decreased salivary flow rate $(\mathrm{OR}=1.58)$ and a $\mathrm{DMFT} \geq 5$ score in subjects, in contrast with adolescents with a DMFT < 5, and, moreover, found that, as the subjects' salivary $\mathrm{pH}$ decreased $(\mathrm{OR}=0.24)$, the probability of caries $(\mathrm{DMFT} \geq 5)$ increased. Various studies have found an association between dental caries and different salivary parameters, including salivary flow rate, buffer capacity, and increased levels of Streptococcus mutans [14, 21].

Although the literature reveals controversial results for the associations between salivary parameters and caries, most research has reported a high prevalence of caries in subjects with a decreased salivary flow rate, decreased buffer capacity, and early and/or high colonization counts for Streptococcus mutans in saliva [22].

Prabhakar A et al. evaluated the relationship between salivary parameters in children both with and without caries, finding reduced salivary flow, $\mathrm{pH}$, and buffer capacity in children with the presence of caries [23]. Moreover, Gábris $\mathrm{K}$ et al. reported a correlation between salivary parameters and the presence of dental caries [24]. The evaluation, in specific age groups (in this instance adolescents), of salivary parameters related to caries is of great importance, as most risk factors have specific consequences for different age groups. Adolescent patients need more comprehensive cariesmanagement strategies in order to avoid the appearance of new incipient and cavitated caries lesions, strategies which include good eating habits, fluoride use, and daily toothbrushing with fluoridated toothpaste, in addition to regular visits to the dentist. All such measures aim to reduce the occurrence of dental caries and positively impact adolescents' quality of life.

The properties of saliva have an essential role in protecting against caries and preventing the progression of carious lesions, given its buffer capacity and the fact that it helps to wash the dental surface, eliminates bacteria and controls demineralization and remineralization in enamel, in addition to other mechanisms that contribute to protecting dental health [25]. Furthermore, an important function of salivary flow is to dissolve bacterial substrate, wherein, if this flow is diminished, it will not be able to dislodge any of the microorganisms adhered to the epithelial tissue of the oral cavity. Moreover, reduced salivary flow will decrease the protective components contained in saliva, which will result in reduced $\mathrm{pH}$, demineralization, and the advancement of the caries process $[14,26]$.

In the present study, a decrease in both salivary $\mathrm{pH}$ $(p=0.001)$ and buffer capacity $(p=0.020)$ was observed among adolescents with DMFT $\geq 5$, in contrast with adolescents with DMFT $<5$. In addition, a significant negative correlation was found between the subject's DMFT score and their salivary $\mathrm{pH}$ and buffer capacity, with this finding similar to results obtained by research conducted in other countries. In a sample of 312 subjects in Saudi Arabia, Farsi reported a relationship between salivary $\mathrm{pH}$

Table 4 Adjusted odds ratios from the logistic regression model for the dental caries (DMFT $\geq 5$ ) in adolescents from 12 to 14 years from Mexico

\begin{tabular}{|c|c|c|c|c|}
\hline Variables & Odds Ratio Crude $(95 \% \mathrm{Cl})^{\mathrm{a}}$ & $p$ & Adjust Odds Ratio $(95 \% \mathrm{Cl})^{\mathrm{a}}$ & $p$ \\
\hline Age $^{b}$ & $1.42(0.98-2.05)$ & 0.062 & $1.04(0.69-1.56)$ & 0.831 \\
\hline Sex ${ }^{c}$ & $1.65(1.11-2.44)$ & 0.012 & $1.57(1.03-2.38)$ & 0.035 \\
\hline Oral Hygiene $(\mathrm{OHI}-\mathrm{S})^{d}$ & $1.88(1.18-2.99)$ & 0.007 & $1.69(1.03-2.74)$ & 0.035 \\
\hline Toothbrushing frequency ${ }^{e}$ & $1.57(1.03-2.40)$ & 0.035 & $1.68(1.07-2.63)$ & 0.023 \\
\hline Mother's level of education ${ }^{f}$ & $1.70(1.14-2.53)$ & 0.009 & $1.59(1.05-2.43)$ & 0.030 \\
\hline Salivary $\mathrm{pH}$ stimulated $^{\mathrm{g}}$ & $0.18(0.08-0.39)$ & 0.001 & $0.24(0.10-0.55)$ & 0.001 \\
\hline Flow rate ${ }^{h}$ & $1.78(1.20-2.64)$ & 0.004 & $1.58(1.04-2.40)$ & 0.033 \\
\hline
\end{tabular}

${ }^{\mathrm{a}}$ OR Odds ratio, $\mathrm{Cl}$ Confidence interval. Reference group: $\mathrm{Age}^{\mathrm{b}}=$ continuous, Sex $^{\mathrm{c}}=$ Boys, OHI-S ${ }^{\mathrm{d}}=$ Good, $_{\text {Toothbrushing frequency }}{ }^{\mathrm{e}} \geq 2$ times a day, Mother's level of education ${ }^{f}=$ Technical or University, Salivary pH stimulated ${ }^{g}=$ continuous, Flow rate $^{\mathrm{h}}=\geq 1 \mathrm{ml}$ per-min Log likelihood $=-259.45519$, Hosmer-Lemeshow $=0.4923$ 
and the presence of caries [27]. Similarly, the decreased $\mathrm{pH}$ and buffer capacity observed could also be due to intrinsic factors (such as bicarbonate and phosphate levels, and protein buffer systems) [28] or extrinsic factors (such as oral hygiene and food).

Research has reported that the buffer capacity of saliva is altered by metabolic and hormonal changes, as well as the subject's health in general [26]. The present study found that salivary flow $(p=0.045)$ and buffer capacity $(p<0.001)$ were higher in boys than in girls. GalvãoMoreira et al. investigated the salivary parameters related to caries susceptibility in boys and girls, finding that girls had lower salivary $\mathrm{pH}$ values than boys $(p<$ 0.05 ) and noting that gender was a predictor of both salivary flow $\left(\mathrm{R}^{2}=0.05 ; p<0.05\right)$ and $\mathrm{pH}\left(\mathrm{R}^{2}=0.16 ; p<\right.$ 0.001) [29].

The participants in the present study showed a high prevalence of DMFT $\geq 5$ score, approximately $61 \%$, which could be a consequence of the subjects' limited access to health services resulting from their low socioeconomic status. Despite the majority reported used fluoride toothpaste, less than half reported brushing their teeth $>2 x /$ day $(33.7 \%)$. The fluoride toothpaste has been shown to play an important role in caries prevention, which not only removes plaque, which mostly comprises bacteria that increases the risk of oral disease but can also be used to apply fluoride onto the teeth [30]. The benefits of using fluoride paste to prevent dental caries in children and adolescents have also been demonstrated in a systematic review [31]. In the present study more than 90\% mentioned using toothpaste, but approximately less than $50 \%$ of children brush $>2 \mathrm{x} /$ day and $70 \%$ have poor hygiene. So, we could say that children have low knowledge about the use of toothpaste, toothbrushing and oral hygiene.

Lack of toothbrushing ( $\mathrm{OR}=1.68 ; p=0.023)$ and poor oral hygiene $(\mathrm{OR}=1.69 ; p=0.035)$ were associated with the presence of caries in the adolescent subjects of the present study. The accumulation of plaque and the lack of toothbrushing help cariogenic bacteria to pass through and destroy the enamel more quickly, with subjects with poor oral hygiene presenting higher caries rates [32]. Research conducted on a population of adolescents aged between 12 and 15 in Spain reported that 12-year-old individuals who reported occasionally brushing their teeth $(\mathrm{OR}=1.83 ; p=0.028)$ presented plaque $(\mathrm{OR}=2.03 ; p=0.021)$ and higher caries values [33], results which were similar to those found in the present study.

Finally, it has been reported that the subject's mother's educational level is related to the presence or absence of dental caries [34]. A study undertaken in Italy in a population of four-to-fourteen-year-old children found that the presence of caries was higher in children whose mothers had a lower educational level $(\mathrm{OR}=6.1)$ [34]. The present study found a relationship between caries and a low educational level in the subject's mother $(\mathrm{OR}=1.59)$.

One of the limitations of this study is the type of convenience sampling used where not all adolescents in the study area were likely to be chosen, another limitation was that salivary buffer capacity was evaluated with strips and not with laboratory tests, which would help to give more precise information. Finally, another limitation in this study is the socio-economic level with the aim of knowing the different economic and social conditions of the population and their distribution with salivary parameters and caries.

\section{Conclusions}

The present study found a significant association in salivary flow rate, $\mathrm{pH}$, and buffer capacity levels in adolescents with caries (DMFT $\geq 5)$, in addition to observing differences in these parameters by sex. In general, a decreased salivary flow increases the probability of presenting more caries. The results of the present study suggest that the levels of these saliva parameters may be used as indicators of the state of caries in adolescents.

\section{Abbreviations \\ CONAPO: Consejo Nacional de Población or National Population Council; \\ OHI-S: Simplified Oral Hygiene Index; WHO: World Health Organization; \\ DMFT: Decayed (D), Missing (M), Filled (F), teeth; OR: Odds Ratio; \\ $\mathrm{Cl}$ : Confidence Interval}

\section{Acknowledgements}

The authors acknowledge the support of Faculty of Higher Studies (FES), Iztacala, of the National Autonomous University of Mexico (UNAM), Mexico.

\section{Authors' contributions}

A.E.G-A-P. designed the study, collected the data, reviewed the manuscript and contributed to discussion; A.G-P. contributed to analyze the data, led the writing, reviewed the manuscript and contributed to discussion; F.G-G reviewed the manuscript and contributed to the discussion. The author(s) read and approved the final manuscript.

\section{Funding}

This work was supported by UNAM-PAPIIT IA207320.

\section{Availability of data and materials}

The datasets used and analyzed during the current study are available from the corresponding author on reasonable request.

\section{Ethics approval and consent to participate}

Ethical approval: All procedures performed in studies involving human participants were in accordance with the ethical standards of the institutional and/or national research committee, and with the 1964 Helsinki declaration and its later amendments or comparable ethical standards. Informed consent: Informed consent was obtained from all individual participants included in the study.

Informed consent was obtained from the parents of the participating children and permission for the study was granted by the Ethics Committee of the Faculty of Higher Studies Iztacala at the National Autonomous University of Mexico (CE/FESI/102017/1209). Informed consent was written.

Consent for publication

Not applicable in this section. 


\section{Competing interests}

The authors declare that they have no competing interests.

\section{Author details}

${ }^{1}$ Faculty of Higher Studies (FES), Iztacala, National Autonomous University of Mexico (UNAM), Avenida de los Barrios Número 1, Colonia Los Reyes Ixtacala, C.P. 54090 Tlalnepantla, Estado de México, Mexico. ${ }^{2}$ Bioscience Research Center, College of Dentistry, University of Tennessee Health Science Center, Memphis, TN, USA.

Received: 2 March 2020 Accepted: 29 June 2020

Published online: 06 July 2020

\section{References}

1. Frencken JE, Sharma P, Stenhouse L, Green D, Laverty D, Dietrich T. Global epidemiology of dental caries and severe periodontitis - a comprehensive review. J Clin Periodontol. 2017:44:S94-S105.

2. Conrads G, About I. Pathophysiology of dental caries. Monogr Oral Sci. 2018; 27:1-10.

3. Hojo S, Komatsu M, Okuda R, Takahashi N, Yamada T. Acid profiles and pH of carious dentin in active and arrested lesions. J Dent Res. 1994;73:1853-7.

4. Henne K, Rheinberg A, Melzer-Krick B, Conrads G. Aciduric microbial taxa including Scardovia wiggsiae and Bifidobacterium spp. in caries and caries free subjects. Anaerobe. 2015:35:60-5.

5. Spielmann N, Wong DT. Saliva: diagnostics and therapeutic perspectives. Oral Dis. 2011;17:345-54.

6. Do T, Damé-Teixeira N, Naginyte M, Marsh PD. Root surface biofilms and caries. Monogr Oral Sci. 2017;26:26-34.

7. Marsh PD, Do T, Beighton D, Devine DA. Influence of saliva on the oral microbiota. Periodontol. 2016:70:80-92.

8. Tenovuo J. Salivary parameters of relevance for assessing caries activity in individuals and populations. Community Dent Oral Epidemiol. 1997;25:82-6.

9. Sekhri P, Sandhu M, Sachdev V, Chopra R. Estimation of trace elements in mixed saliva of caries free and caries active children. J Clin Pediatr Dent. 2018:42:135-9.

10. Twetman S. Prevention of dental caries as a non-communicable disease. Eur J Oral Sci. 2018;126:19-25.

11. Stone VN, Xu P. Targeted antimicrobial therapy in the microbiome era. Mol Oral Microbiol. 2017;32:446-54.

12. Molina-Frechero N, Castañeda-Castaneira E, Marques-Dos-Santos MJ, SoriaHernández A, Bologna-Molina R. Dental caries and risk factors in adolescents of Ecatepec in the state of Mexico. Rev Investig Clin. 2009;61: 300-5.

13. Karlsson F, Stensson M, Jansson H. Caries incidence and risk assessment during a five-year period in adolescents living in South-Eastern Sweden. Int J Dent Hyg. 2020;18:92-8.

14. Pyati SA, Naveen Kumar R, Kumar V, Praveen Kumar NH, Parveen Reddy KM. Salivary flow rate, ph, buffering capacity, total protein, oxidative stress and antioxidant capacity in children with and without dental caries. J Clin Pediatr Dent. 2018:42:445-9.

15. Broadbent JM, Foster Page LA, Thomson WM, Poulton R. Permanent dentition caries through the first half of life. Br Dent J. 2013;215:E12.

16. Cunha-Cruz J, Scott J, Rothen M, Mancl L, Lawhorn T, Brossel K, Berg J. Northwest Practice-based REsearch Collaborative in Evidence-based DENTistry Salivary characteristics and dental caries: evidence from general dental practices. J Am Dent Assoc. 2013;144:e31-40.

17. CONAPO 2015. [marginalization index by state and municipality]. http:// www.conapo.gob.mx/es/CONAPO/Datos_Abiertos_del_Indice_de_ Marginacion accessed 02 march 2020.

18. Irigoyen ME, Maupomé G, Mejía AM. Caries experience and treatment needs in a 6- to 12-year-old urban population in relation to socio-economic status. Community Dent Health. 1999;16:245-9.

19. González-Aragón Pineda ÁE, Borges-Yáñez SA, Irigoyen-Camacho ME, Lussi A. Relationship between erosive tooth wear and beverage consumption among a group of schoolchildren in Mexico City. Clin Oral Investig. 2019;23: 715-23.

20. World Health Organization. Oral Health Surveys: Basic Methods. 5th ed. Geneva: WHO; 2013.

21. Sakeenabi B, Hiremath SS. Dental caries experience and salivary Streptococcus mutans, lactobacilli scores, salivary flow rate, and salivary buffering capacity among 6-year-old Indian school children. J Int Soc Prev Community Dent. 2011;1:45-51.

22. Gao X, Jiang S, Koh D, Hsu CY. Salivary biomarkers for dental caries. Periodontol. 2016;70:128-41.

23. Prabhakar A, Dodawad R, Os R. Evaluation of flow rate, ph, buffering capacity, calcium, total protein and total antioxidant levels of saliva in caries free and caries active children-an in vivo study. Int J Clin Pediatr Dent. 2009; 2:9-12.

24. Gábris K, Nagy G, Madléna M, Dénes Z, Márton S, Keszthelyi G, Bánóczy J. Associations between microbiological and salivary caries activity tests and caries experience in Hungarian adolescents. Caries Res. 1999;33:191-5.

25. Dowd FJ. Saliva and dental caries. Dent Clin N Am. 1999;43:579-97.

26. Lenander-Lumikari M, Loimaranta V. Saliva and dental caries. Adv Dent Res. 2000;14:40-7.

27. Farsi N. Dental caries in relation to salivary factors in Saudi population groups. J Contemp Dent Pract. 2008;9:16-23.

28. Bardow A, Moe D, Nyvad B, Nauntofte B. The buffer capacity and buffer systems of human whole saliva measured without loss of $\mathrm{CO}_{2}$. Arch Oral Biol. 2000;45:1-12

29. Galvão-Moreira LV, de Andrade CM, de Oliveira JFF, Bomfim MRQ Figueiredo PMS, Branco-de-Almeida LS. Sex differences in salivary parameters of caries susceptibility in healthy individuals. Oral Health Prev Dent. 2018;16:71-7.

30. Leary SD, Do LG. Changes in oral health behaviours between childhood and adolescence: findings from a UK cohort study. Community Dent Oral Epidemiol. 2019:47:367-73.

31. Walsh T, Worthington HV, Glenny AM, Marinho VC, Jeroncic A. Fluoride toothpastes of different concentrations for preventing dental caries. Cochrane Database Syst Rev. 2019;3:CD007868.

32. Fejerskov O, Kidd E. Dental caries: the disease and its clinical management. Oxford: Blackwell Munksgaard; 2008.

33. Obregón-Rodríguez N, Fernández-Riveiro P, Piñeiro-Lamas M, SmythChamosa E, Montes-Martínez A, Suárez-Cunqueiro MM. Prevalence and caries-related risk factors in schoolchildren of 12- and 15-year-old: a crosssectional study. BMC Oral Health. 2019;19:120.

34. Cianetti S, Lombardo G, Lupatelli E, Rossi G, Abraha I, Pagano S, Paglia L. Dental caries, parents educational level, family income and dental service attendance among children in Italy. Eur J Paediatr Dent. 2017;18:15-8.

\section{Publisher's Note}

Springer Nature remains neutral with regard to jurisdictional claims in published maps and institutional affiliations.

\section{Ready to submit your research? Choose BMC and benefit from:}

- fast, convenient online submission

- thorough peer review by experienced researchers in your field

- rapid publication on acceptance

- support for research data, including large and complex data types

- gold Open Access which fosters wider collaboration and increased citations

- maximum visibility for your research: over $100 \mathrm{M}$ website views per year

At $\mathrm{BMC}$, research is always in progress.

Learn more biomedcentral.com/submissions 